\title{
Translation Techniques of Modality Metaphor in Novel Anne of Green Gables
}

\author{
Yurike Suhertian Poyungi, \\ M.R. Nababan, \\ Riyadi Santosa \\ Sebelas Maret University, \\ Surakarta, Indonesia \\ yurikesuhertian@gmail.com \\ Article History: Submitted on $21^{\text {th }}$ April 2021; Accepted on $24^{\text {th }}$ May 2021; \\ Published on $30^{\text {th }}$ June 2021
}

\begin{abstract}
This is a descriptive qualitative research that aims to analyze the types of modality metaphor and their translation techniques in the novel entitled Anne of Green Gables. It is a translation research using Systemic Functional Linguistic (SFL) approach. Data were collected by content analysis and focus group discussion (FGD). The data were analyzed by Spradely's data analysis method. The content analysis is used to analyze the types of modality metaphor based on Halliday and Matthiessen' theory. Furthermore, the translation technique is analyzed by Molina and Albir's classification and is done by focus group discussion. This research results that there are two types of modality metaphor found in the novel, they are probability and obligation. Moreover, the translation techniques that used to translate the modality metaphor are established equivalence, compensation, paraphrase, modulation, deletion, discursive creation and implicitation. The use of these translation techniques shows the translator creativity to translate the modality metaphor.
\end{abstract}

Keywords: modality metaphor, types of modality metaphor, translation techniques. 


\section{INTRODUCTION}

Language can be interpreted as one of human expressions. It is through language, human can express their feelings, thoughts, opinion and desires. Language is needed by human being to organize, to represent or to exchange their experience. Thus, language is system for making meaning (Halliday, 1985). It means that the language function is to deliver meaning of the interaction from speaker to listener. The interaction can be done by written or oral. This study will focus on written text.

In written text, the users of language represent their experience by using a clause. One aspect that used by speaker or listener in the clause is the use of modality. Modality is a complex area of English grammar because it concerns to the various ways which speaker expresses his or her attitude or opinion toward the truth of what he or she says (Dong, 2013). The speaker certainly uses modality markers to describe the degree of certainty. Accordingly, it can affect the understanding of the readers or listeners in comprehending the messages in the story (Aritonang, 2014). However, modalities are not always realized congruently using modal elements in the clause, but it can be realized metaphorically in separated clause. This phenomenon called modality metaphor. In Systemic functional linguistic's perspective (SFL), modality metaphor is based on relation of semantic projection. It could show speaker opinions based on probability that is coded in separated clause of projecting clause in clause complex (Halliday and Matthiessen, 2014).

The realization of modality metaphor that found in English particularly different in Indonesian. It is due to the difference of language structures and systems in both languages. This is the reason why translation is needed.

In general, translation is the communication of meaning from one language (as known as source language) into another language (as known as target language). In addition, Catford (1965) states that translation is the replacement of textual material in one language (SL) by equivalent material in another language (TL). In line with Catford's statement, translation is the act of transferring the linguistic entities from one language into their equivalents in another language (Osman, 2017). Therefore, translator should notice the forms of modality metaphor in source language so that he or she could transfer it into the target language equivalently.

Moreover, in translation studies known the terms translation techniques, method and translation strategy. According to Molina and Albir (2002) the use of these terms and concepts overlaps because there is no general agreement about the instrument analysis and there is a confusion of the use the terminology, concept and classification. Therefore, they argued that should be a distinction between the terms of translation technique, method and strategy. It is clarified in their journal entitled Translation 
Techniques Revisited: A Dynamic and Functionalist Approach. Translation method is a global choice toward the whole translation and it is part of translation process. That is mean that translation method related to the choice taken by the translator and the choice affects the whole text. It is done based on the translator purpose or specifically the translation purpose itself. Meanwhile, translation techniques describe the result that obtained and could use to classify a variety kinds of translation studies. In other words, it refers to translation products and works for the micro unit of the text (Molina \& Albir, 2002). Accordingly, the translation method such as adaptation or literal affects the whole text as it is in the macro units whereas translation technique such as adaptation or literal affects the micro units in the text. Moreover, translation strategy is procedures or ways used by the translator consciously nor unconsciously, verbal or non-verbal to cope with the problems when going through translation process with specific purpose in her or his mind. Shortly, translation strategy will be need by the translator when they face any problems during translation process. From the explanation, there are two keywords about translation: translation is a process and products. The translation products are very diverse and have their own audience. One of them is novel. Novel is also included in written text.

In order to transfer the modality metaphor into target language, translators are able to use a wide variety of translation techniques to translate it accurately. That is why translation techniques are used to come up with an accurate translation (Fitria, 2020).

The studies of modality metaphor have been done before. Here are some of them. First, a study about assertiveness from observation results of students debate including the use of modality metaphor (Yuyun, 2014). Second, a discussion about metaphor of modality and its function in English advertisement (Xu, 2009). Then, an examination of interpersonal metaphor of modality in persuasive texts (To \& Thomas, 2017). Fourth, a discussion about metaphorical framing in The Financial Times and II Sole 24 Ore 2008 (Luporini, 2013). His discussion also included modality metaphor. The four studies have not been investigated modality metaphor and translation. On the other hand, the study about modality metaphor and translation finally have been discussed by Dinagara (2016). He examined about the procedures and method that used by students to translate the grammatical metaphor including modality metaphor. However, all the previous researchers have not been explored the translation techniques of modality metaphor itself.

Based on the explanation above, this present study will focus on the translation techniques of modality metaphor. Since the translation technique is in the micro units, it can be the instrument analysis in assessing the translation result. The concept that offered in this study is an analysis of a translation of modality metaphor and it leads to the translation product specifically novel. The result that to be achieved from this work is to know the translation techniques of modality that used in the novel.

As the basis of this research, the following is some examples of the 
data:

1). ST : I don't think I could endure it

TT : Kupikir aku tak akan mampu menjalaninya

2). ST : We thought we'd get a boy

TT : Kami berpikir akan mengambil seorang anak laki-laki.

From the two examples above, it can be analyzed type of modality metaphor that used. Then, it continues with the analysis of its translation techniques.

Therefore, the objectives of this study are to analyze the types the types of modality metaphor found in novel Anne of Green Gables and to classify their translation techniques. In addition, this present study is expected to support the previous researches particularly in translation studies.

\section{METHOD}

This research belongs to descriptive qualitative research. According to Moleong (2010), qualitative research is a research aims to develop the understanding about individuals and the events and stay pay attention to the relevant context. Meanwhile, based on its characteristics, design of this research is flexible and overt. It means that this research design can be adapted to the finding realities, if there are more interesting findings when doing the research (Lincoln and Guba in Santosa, 2017). It is a descriptive research because this research more focus on the data in term of words, sentences or pictures that have meaningful meaning and give trigger to a more concrete understanding than just numbers or frequencies presentation (Sutopo, 2006). In addition, it is a descriptive research because of the use of pictures, tables, diagrams etc so that the description about the linguistic phenomenon that researched can be described systematically and holistically.

The source of the data is a novel entitled Anne of Green Gables both its Englis and Indonesian version. It is written by Lucy M. Montgomery and translated into Indonesian by Maria M. Lubis. Thus, this research leads to translation product. Data of this research are the clauses that realized modality metaphor and their translation techniques.

Data were collected by content analysis and focus group discussion (FGD). In content analysis, there are two steps that have been done by the researcher. First, the researcher marked and wrote all the data in term of modality both in source text (ST) and target text (TT). Second, classified the types of modality metaphor using Halliday and Mathiessen's theory (2014). Meanwhile, in FGD, the researcher discussed and determined the translation techniques based on the classification of Molina and Albir (2002). After all the data collected, the data were validated by source triangulation and method triangulation.

Since this research used the content analysis, there are four stages of the data analysis. The four stages of analysis, namely domain, taxonomy, 
component and cultural theme analysis (Spadely, 1980). Firstly, the researcher distinguished data and non-data by reading the whole novel carefully. Data and non-data are distinguished by the forming elements of modality metaphor in all clauses. Then, the data are identified by types of modality metaphor. The identification and analysis of modality metaphor still takes into account to the context of situation. Secondly, the analysis is continued by analyzing the translation techniques. This analysis is carried out by discussing the translation techniques in FGD with the raters who have the capability in translation studies and linguistics. To make the discussion easier, the researcher also distributed the questionnaires that containing the data of modality metaphor and the column of the translation technique will be filled during the discussion. Thirdly, the researcher connected the relation between the types of modality metaphor and their translation techniques that applied by the translator in the novel. Finally, after having the correlation between the types of modality metaphor and their translation techniques, the researcher reconnected the result of this present study with the related previous researches and the ground theory used to have the more detail discussion.

\section{FINDINGS AND DISCUSSION}

Based on the analysis that had done by the researcher, it is found that there are two types of modality metaphor in the novel. In addition, there are seven translation techniques used to translate the modality metaphor. The findings will be described in the following table:

Table 1:

The Types of Modality Metaphor and Their Translation Techniques

\begin{tabular}{|c|c|c|}
\hline $\begin{array}{c}\text { Types of Modality } \\
\text { Metaphor }\end{array}$ & $\begin{array}{c}\text { Translation } \\
\text { Techniques }\end{array}$ & Frequency \\
\hline \multirow{4}{*}{ Probability } & $\begin{array}{c}\text { Established } \\
\text { equivalence }\end{array}$ & 157 \\
\cline { 2 - 3 } & Modulation & 19 \\
\cline { 2 - 3 } & Compensation & 6 \\
\cline { 2 - 3 } & Paraphrase & 6 \\
\cline { 2 - 3 } & Discursive creation & 1 \\
\cline { 2 - 3 } & Implicitation & 1 \\
\cline { 2 - 3 } & Deletion & 5 \\
\hline Obligation & $\begin{array}{c}\text { Established } \\
\text { equivalence }\end{array}$ & 19 \\
\hline
\end{tabular}




\begin{tabular}{|c|c|}
\hline & paraphrase \\
\hline Total & 215 \\
\hline
\end{tabular}

Table 1 shows that the two types of modality metaphor are modalization (probability) and modulation (obligation). Each type will be explained in the following parts:

\section{Types of Modality Metaphor}

\section{a. Modalization (probability)}

Halliday and Matthiessen (2014) defines that if a clause is a proposal (giving and demanding information, it refers to modalization. This means either 'yes' or 'no' i.e maybe shows probability or 'both yes and no' i.e sometimes shows usuality. Here are the examples of finding in this research:

(a) I suppose-we could hardly be expected to keep her

The clause (a) is a projecting clause that realized modality metaphor. It is realized by projecting mental clause I suppose as mood adjunct. The modality metaphor identified as probability. The clause is a proposal clause that expressed by Matthew Cuthbert to his sister, Marilla Cuthbert. The modality metaphor I suppose showed the degree of certainty related to maybe yes or may be subjectively toward what he is saying.

(b) Matthew Cuthbert, I believe that child has bewitched you!

Another example of probability described on example (b). The projecting mental clause realized by $\mathbf{I}$ believe that expressed by Marilla. The mental clause I believe also expressed the probability subjectively about what happened to Matthew. This clause refers to proposal clause.

\section{b. Modulation (obligation)}

If a clause is a proposition clause (giving and demanding goods and services), it deals with modulation. This type divided into obligation 'is wanted to' and inclination 'wants to.' (Halliday and Matthiessen, 2014). Here is the finding of this types:

(c) I wanted you to behave nicely to Mrs. Lynde, and instead of that you have disgraced me.

The clause (c) is identified as obligation that realized by projecting mental clause I wanted you. It is a proposition clause and the modality metaphor I wanted you show the obligation that expressed subjectively by Marilla as 
the speaker to Anne as the hearer. This means that Anne is expected to obey what Marilla is saying to her.

As explained by Halliday and Matthiessen (2014) that modality metaphor describes speaker opinion based on the probability which is coded not as modal element in the clause e.g "it probably it is" which is a congruent realization, but in the separated clause through projecting clause in the hypotactic clause nexus, so that the realization is metaphorical e.g "I think it so." The findings of this research are related to Halliday and Matthiessen theory that each types of modality metaphor are realized by the projecting mental clauses and relational clauses. Moreover, some previous studies such as Dong (2013) and Yuyun (2014) have not discussed the modality metaphor specifically. They only discussed about the realization of modality metaphor just like the research that had done by Xu (2009). Otherwise, this present research is related to Halliday and Matthiessen (2014) stated before that metaphor modality shows the degree of certainty of speaker opinion in a separated clause. Probability and obligation are used to convey opinion or attitude of the characters toward the events in the novel.

\section{Translation Techniques of Modality Metaphor}

Molina and Albir (2002) classifies 18 translation techniques. They are, , amplification, borrowing, adaptation, calque, reduction, compensation, description, linguistic amplification, variation, established equivalence, transposition, literal translation, modulation, generalization, particularization, linguistic compression, and subtitution,

As described on table 1 , there are seven translation techniques that applied to translate the modality metaphor. The most dominant translation technique is established equivalence. Next, followed by the use of modulation, compensation, paraphrase and deletion. Meanwhile, discursive creation and implicitation are the lowest ones in frequency. The seven translation techniques that found in this research will be explained below:

\section{a. Established Equivalence}

Established equivalence applied when the translator uses the familiar expressions or words in TT.

(d) ST: I guess she hadn't any father or mother of her own

\section{TT: Kupikir ia tidak memiliki ayah atau ibu}

The finding (d) is one of examples of established equivalence. Modality metaphor I guess is translated kupikir. It shows that the translator using the familiar words or expression in TT. 


\section{b. Modulation}

Modulation is applied by changing the point of view, cognitive category, or focus in TT. The change occurs not only in lexical level but also in structural level.

(e) ST: I don't suppose you are any more surprised that I am myself

\section{TT: Kupikir kau tak akan lebih kaget daripada aku sendiri.}

The projecting clause I don't suppose translated kupikir. The clause should translate ku tak berpikir, but the translator seems to change the point of view in TT. The negative polarity that realized by the projecting clause is changed so that the negative polarity is the projected clause kan tak akan lebih kaget daripada aku sendiri. It causes the change in level of lexical, however the meaning and type of modality metaphor does not change.

\section{c. Paraphrase}

Paraphrase is an expansion of amplification. This technique is the dominant one after established equivalence and modulation. As its name, paraphrase is used when the translator paraphrasing the words or expressions in TT.

(f) ST: I suppose I can have the mare and buggy this afternoon, Matthew?

\section{TT: Apakah aku bisa memakai kuda dan kereta bugi sore ini, Matthew?}

The application of paraphrase described in the clause (f). In ST, modality metaphor I suppose is identified as modalization:probability. When it translated, the modality metaphor I suppose is paraphrased become interrogative sentence apakah. It occurs because the translator wants to transfer the meaning of the clause in accordance with rules in TT. In the target language, the proposal clause should begin with an interrogative.

\section{d. Compensation}

Compensation is a translation technique that change particular position differently in ST and TT. It is done due to the stylistic effect in ST that cannot be applied in TT. There are four types of compensation, they are compensation in place, compensation by splitting, compensation in kind, and compensation by merging.

(g) ST: Diana might just have smiled at me once, I think.

\section{TT: Kupikir Diana seharusnya tersenyum sekali saja padaku.}

In clause (g), it can be seen clearly the use of compensation. In ST, modality metaphor I think is in the subordinate clause, however when it 
translated, it moves to the main clause in TT. This flitting absolutely does not affect the meaning or types of modality metaphor.

\section{e. Deletion}

If reduction functions to omit partial information, deletion is a totally omitting from ST to TT. Therefore, the meaning that contained in ST changes.

(h) ST: It's not likely I'd refuse to let you go

\section{TT: Dan aku tidak akan melarangmu pergi}

The clause (h) shows the use of deletion. The relational clause it is not likely has not translated by the translator. In other words, the modality metaphor in TT is deleted so that the meaning of modality metaphor in clause changes.

\section{f. Implicitation}

Implicitation is used when the translator wants to imply expressions or words from ST into TT.

(i) ST: That was why I was so glad when I thought I was going to live here

TT: Itulah alasan mengapa aku begitu gembira ketika berpikir aku akan tinggal di $\sin \mathrm{i}$

Modality metaphor in projecting mental clause $\mathbf{I}$ thought is implied berpikir by the translator. The choice to imply the modality metaphor not decreased the meaning of it.

\section{g. Discursive creation}

It is commonly used to translate titles so therefore its equivalency in TT is totally out of context.

(j) ST: I don't think though, that I ought to go very often to horse races.

\section{TT: Kupikir aku harus sering-sering melibat pacuan kuda}

The translator used discursive creation technique when she translated the modality metaphor I don't think become Kupikir. The negative polarity of modality metaphor translated as positive polarity in T'T.

As explained before that this present study will focus on the translation of modality metaphor specifically on translation techniques. Result of the previous study that had done by Dinagara (2016) showed that the translator who is the students of English department in Pendidikan Indonesia University need improvement to recognize the grammatical metaphor 
(included modality metaphor as interpersonal metaphor) and to use the relevant method and procedures to translate it. This means that the use of methods, procedures, techniques and strategies in translation activity is required. Thus, translator's background and competency also are influential in analyzing the form of modality metaphor that realized in clauses. The aim is the modality metaphor is maintained when it translated in TT. In addition, the use of translation techniques shows translator's creativity in translating the modality metaphor. As mentioned before that the use of translation techniques also has impact to the translation quality. In this research shows that the translator tends to apply the established equivalence to translate the modality metaphor is intended to produce the quality translation.

\section{CONCLUSION}

Based on the finding and discussion above can be concluded that the types of modality metaphor that found in the novel Anne of Green Gables are modalization (probability) and modulation (obligation). The two types of modality metaphor used to convey speaker opinion toward what he or she is saying. Seven out of eighteen translation techniques are used by the translator to translate the modality metaphor in Indonesian version of Anne of Green Gables including established equivalence, modulation, paraphrase, compensation, deletion, implicitation and discursive creation. The most dominant translation technique is established equivalence. The use of these translation techniques impacts the translation quality. Accordingly, this present study can contribute in translation study particularly can be reference for the translators to find out the relevant translation techniques to produce the good and quality translation. 


\section{REFERENCES}

Aritonang, D. K. (2014). Impacts of Interpersonal Metaphor on Grammatical Intricacy and Lexical Density in The Text of Presidential Debate between Barrack Obama and Mitt Romney" Jurnal Pendidikan Tabularasa.1, 13-25. Retrieved from https://jurnal.unimed.ac.id/2012/index.php/tabularasa/article/vie $\mathrm{w} / 3259$

Catford, J. C. (1965). Linguistic Theory of Translation. London: Oxford University Press.

Dinagara, R.S. (2016). Grammatical Metaphor as Framework Analysis of Students's Translation of Discussion Text (A Case Study of English Department's Students in Indonesia University of Education.” Journal of English and Education. Retrieved from https://ejournal.upi.edu/index.php/L-E/article/view/4622/3221

Dong, J. (2013). Interpersonal Metaphor in Legal Discourse: Modality in Cross-examinations. Journal of Language Teaching and Research, 4(6), 1311-1321. https://doi.org/10.4304/jltr.4.6.1311-1321

Fitria, T. N. (2020). Translation Technique of English to Indonesian Subtitle in "Crazy Rich Asian" Movie. ELS Journal on Interdisciplinary Studies in Humanities, 3(1), 51-65. https:/ / doi.org/10.34050/elsjish.v3i1.8415

Halliday, M.A.K \& Hasan, R. (1985). Language, Context, and Text: Aspect of Language in a Social-Semiotic Perspective. Melbourne: Deakin University

Halliday, M.A.K \& Mathiessen, C. (2014). Halliday's Introduction to Functional Grammar.London: Hodder Arnold.

Luporini, A. (2013). Metaphor in Times of Crisis: Metaphorical Representations of the Global Crisis in The Financial Times and II Sole 24 Ore 2008.

http://www.isfla.org/Systemics/Print/Theses/Luporini_PhD_Thesis. $\operatorname{pdf}$

Moelong, L.J. (2010). Metode Penelitian Kualitatif. Bandung: PT. Remaja Rosdakarya.

Molina, L., \& Albir, A. H. (2002). Translation techniques revisited: A dynamic and functionalist approach. Meta, 47(4), 498-512. https://doi.org/10.7202/008033ar

Osman, A. (2017). Definition of Translation. Translation Journal, October. ranslationjournal.net/October-2017/definition-of-translation.html

Santosa, R. (2017). Metode Penelitian Kualitatif Kebahasaan. Surakarta: UNS Press. 
Spradely, J. (1980). Participant Observation. Florida: Holt, Rinehart and Winston

Sutopo. (2006). Metode Penelitian Kualitatif. Surakarta: UNS Press

To, V., \& Thomas, D. (2017). Examining interpersonal metaphor of modality in successful primary persuasive texts. 44 th International Systemic Functional ..., 1-6.

https://www.researchgate.net/profile/Nia_Kurniawati4/publication/ 332245371_Developing_EFL_Students'_Descriptive_Writing_throug h_Alternative_Joint_Construction/links/5ca8a3614585157bd325af07/ Developing-EFL-Students-Descriptive-Writing-through-Alternative-J

$\mathrm{Xu}$, J. (2009). Interpreting Metaphor of Modality in Advertising English. English Language Teaching, 2(4), 117-122. https://doi.org/10.5539/elt.v2n4p117

Yuyun, I. (2014). A study of assertiveness in a debate setting. Indonesian Journal of Applied Linguistics, 3(2), 140-153. https://doi.org/10.17509/ijal.v3i2.275 